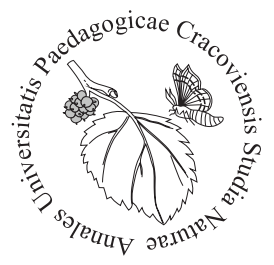

Hamid Dorosti, ${ }^{1}$ Katarzyna Możdżeń, ${ }^{2}$ Peiman Zandi ${ }^{*}$, Morteza Siavoshi ${ }^{4}$

${ }^{1}$ Rice Research Institute of Iran (RRII), P.O. Box 1658, Rasht, Iran ${ }^{2}$ Department of Plant Physiology, Pedagogical University of Kraków, Podchorążych 2, 30-084 Kraków, Poland ${ }^{3}$ Institute of Environment and Sustainable Development in Agriculture, Chinese Academy of Agricultural Sciences, P.O. Box 10081 Beijing, P. R. China; ${ }^{2} \_$rice_b@yahoo.com

${ }^{4}$ Assistant Professor, Department of Agricultural Sciences, Payame Noor University, I.R. of Iran

\title{
The influence of foliar "feeding" of urea on yield and its components of Iranian hybrid rice Oryza sativa L. 'Bahar 1'
}

\section{Introduction}

Rice (Oryza sativa L.) has become a highly strategic and priority crop in approximately half of the global population with regard to procuring energy, proteins, and vitamins (IRRI, 2008). It is mainly cultivated in Asian countries under a hot humid climate in both tropical and temperate regions. Rice is regarded as the major source of food in Iran (population 77 million; $46 \mathrm{~kg}$ per capita/year), with an average annual domestic production of 2.35 million tons of paddy rice grown on 539.000 hectares and an annual consumption of 3.5 million tons (Ahmadi et al., 2014). It is projected that Iran needs to produce 5 million tons of rice by 2035 to achieve self-sufficiency (Akhgari, 2010). The recent rice crisis proves again that a sustainable increase in rice production is crucial for food security in the rice-growing countries of Asia (IRRI, 2008). Hybrid rice technology is a key strategy for increasing rice production and maintaining self-sufficiency and food security (Dorosti, 2009). These rice varieties give about $15-25 \%$ more yield than improved inbred rice in farmers' fields (Xie, Hardy, 2009). Its potential for enhancing rice production and productivity has motivated many countries, like Iran, to exploit this technology. The hybrid rice program in Iran was launched at the Rice Research Institute of Rasht at the beginning of 1987 through establishing a collaborative project together with the International Rice Research Institute (IRRI, 2008), Philippines, as the major factor contributing to the remarkable success of hybrid rice technology in Iran (Dorosti, 2009).

Providing efficient quantities of nutrients needed by plants, in particular the essential elements, is one of the most important factors of crop management (Youse- 
fi, Zandi, 2012). Crop production can be increased through application of fertilisers containing these elements (Shen et al., 2013). Increasing the concentration of essential elements in plants assigns an important role in improving the quality of food products and improves the health of society (Tavakoli et al., 2014). Dwindling water resources, intermittent droughts, low fertility of agricultural lands, the lack of available nutrients, and their low accessibility to the organic resources are among barriers to accessing proper operation in the field of agriculture (Shirani Rad, Zandi, 2014). Fageria (2013) reported that nitrogen is one of the essential elements required for plant growth. Crop plants assimilate nutrients not only through their leaves but as well as the other shooting parts, like young panicles, stems, and flowers. Fresh and swiftly expanding leaves are more streamlined in absorption of foliar-sprayed nutrients from their upper/ lower surfaces than those of fully matured ones (Mondal, Al-Mamun, 2011).

Nitrogen contributes to grain filling through elevating this element content in leaves and to sink size through increasing the hull size and mitigating the number of degenerated spikelets (Singh et al., 2014). Liu et al. (2014) declared that consuming nitrogen fertiliser in a proper time sequence helps to eliminate excessive use of it. Due to the high solubility of nitrogen fertilisers, proper timing of nitrogen application is assumed to be very pivotal in better efficiency of nitrogen use and less loss of this element to the environment (Fageria, 2013). In their study on Aman rice, Bhuyan et al. (2012) demonstrated that foliar application of $\mathrm{N}$ fertiliser in a bed planting method increased yield attributes, such as grain yield, the number of panicles per square meter, the number of grains per panicle, 1000-grain weight, and water use efficiency for biomass and grain production much more than the conventional methods. Singh et al. (2014) suggested that foliar feeding of rice by inputting higher doses of nitrogen fertiliser enhanced the growth dynamic, biomass partitioning, and chaffy grain. However, in their study, nitrogen use efficiency remained unaffected. Furthermore, the yield of rice and components were found to have less attribution to foliar application of urea fertilisation (Hasanuzzaman et al., 2009).

The highest crop in canola was recorded by foliar spraying of nitrogen at the stem elongation or right before the flowering stage (Tousikehal et al., 2011). Azarpour et al. (2011), in their study on rice crops, reported a consecutive enhancement in yield as a result of adding nitrogen to the soil. Although foliar spraying during mead-season had a positive effect on the grain yield of rice crop (Brown, Petrie, 2006; Asadi et al., 2014), the same result in grain protein was noticed exclusively when spraying was done at active tillering and booting stages (Asadi et al., 2015).

In recent decades, agricultural products have mostly relied on the utilisation of chemical inputs, which in itself has detrimental effects on the environment (Zandi, Basu, 2016). Comparatively, the soil application of nitrogenous fertiliser does not appear to be a better method, because it causes the plants to absorb the nutrients 
much slower, and large quantities will be required for normal growth in contrast to the smaller ones of the same generally required for foliar application (Mondal, Al-Mamun, 2011). In particular, the effectiveness of foliar feeding is augmented when the canopy microclimate is occupied by high levels of leaf sources (Akhgari, 2010). Due to the limited or inconclusive information on the efficiency of the foliar application of urea fertiliser on yield attributes and the yield of hybrid rice grown under moderate conditions, it was decided to conduct this research.

The aim of the study was to examine the influence of foliar application of urea fertiliser at active tillering and booting stages on the yield of hybrid rice O. sativa 'Bahar 1 ' and finding out the optimum concentration of urea fertilisation for the maximum yield of rice under moderate climatic conditions. It was hypothesised that different concentrations of foliar application of urea fertiliser would receive more palatable nitrogen fertiliser use efficiency than conventional fertilising method.

\section{Materials and methods}

The field experiment was conducted in Talesh County, Guilan-Iran in 2014, at latitude $48^{\circ} 37^{\prime} \mathrm{N}$ and longitude $54^{\circ} 48^{\prime} \mathrm{E}$, with $45 \mathrm{~m}$ of altitude. The climate, according to Köeppen classification, is Mediterranean with mild winters and warm-humid summers. Most precipitation occurs in late summer and early spring. Soil $\mathrm{pH}$ was determined using glass electrode in a 1: 2.5 soil/water suspension. Available phosphorus $(\mathrm{P})$ in the soil samples was computed by leaching the soil with $0.002 \mathrm{~N}$ sulfuric acid (1 soil: 200 $\mathrm{H}_{2} \mathrm{SO}_{4}$ suspension, w/v) and agitating it for at least half an hour and filtering it through Whatman filter paper No. 42. Available P in the extract was determined spectrophotometrically at the wavelength $690 \mathrm{~nm}$ (Ravikumar, Somashekar, 2013). Leaching the soil sample with $1 \mathrm{~N}$ ammonium acetate at $\mathrm{pH} 7.0(\mathrm{w} / \mathrm{v})$, keeping it for overnight, filtering it through Whatman filter paper No. 42, and brining the volume up to $100 \mathrm{ml}$ with distilled water, the exchangeable $\mathrm{K}^{+}$in soil could be extracted after the method followed by Britzke et al. (2012). The filtrate (sample) containing $\mathrm{K}$ was then used for the flame photometric determination of potassium. The soil analysis showed that the texture of the experimental site $(0-25 \mathrm{~cm})$ was silty clay with $0.71 \mathrm{dS} \mathrm{m}^{-1} \mathrm{EC} ; 6.6$ $\mathrm{pH}\left(\mathrm{H}_{2} \mathrm{O}\right) ; 2.21 \%$ organic matter; $20.1 \mathrm{mg} \mathrm{kg}^{-1}$ available phosphorus; $127 \mathrm{mg} \mathrm{kg}^{-1} \mathrm{ex}^{-}$ changeable potassium, and $0.238 \%$ total nitrogen.

The experiment was laid out in a two-factor randomised complete block design (RCBD) with three nitrogen treatments $\left(\mathrm{N}_{0}, \mathrm{~N}_{10}, \mathrm{~N}_{20} \mathrm{~kg} \mathrm{~N} \mathrm{ha}^{-1}\right)$ and two application times (at tillering and booting stages), and it was replicated three times. Each plot was $3 \times 4 \mathrm{~m}$ in size. Urea fertiliser $\left(\mathrm{CO}\left(\mathrm{NH}_{2}\right)_{2}\right)$, as the best source of actual nitrogen $(46 \%$ $\mathrm{N}$ ) for aerial application (Norton, 2011), was considered for foliar spraying (Control or no $\mathrm{N}$ fertilisation, $10 \mathrm{~kg} \mathrm{~N} \mathrm{ha}^{-1} \approx 22 \mathrm{~kg}$ urea ha ${ }^{-1}, 20 \mathrm{~kg} \mathrm{~N} \mathrm{ha}^{-1} \approx 44 \mathrm{~kg}$ urea ha $^{-1}$ ) 
using a single-nozzle hand sprayer. The urea spray volumes were prepared by mixing $5 \mathrm{~kg}$ of urea in $100 \mathrm{~L}$ of water (i.e. $5 \%$ urea solution) as per treatment (Asadi et al., 2014). The plots were sprayed during late afternoon hours when the wind speed was less than $12 \mathrm{~km} \mathrm{hr}^{-1}$.

The hybrid rice variety of 'Bahar 1' was used that was bred through combining a cytoplasmic male sterile line and a restorer line (IR58025A / IR42686R) (Dorosti, 2009). Fertiliser recommendations for experimental plots were based on soil surveys. Basal fertilisers of nitrogen (50 kg N ha-1), triple superphosphate (160 kg TSP ha-1), and potassium chloride $(50 \mathrm{~kg} \mathrm{KCl} \mathrm{ha-1})$ were applied right before transplanting. An additional amount of potassium chloride $\left(50 \mathrm{~kg} \mathrm{KCl} \mathrm{ha}^{-1}\right)$ was applied at the maximum tillering stage. Crop cultivation was carried out on April $14^{\text {th }}$, and when the seedlings height was about $25 \mathrm{~cm}$ in early May (on May $5^{\text {th }}$ ), they were transferred (three seedlings per hill and $25 \times 25 \mathrm{~cm}$ spacing) to the main field of transplantation. Weeds (Butachlor $4 \mathrm{~L} \mathrm{ha}^{-1}$ ) and pests (Diazinon 5\% granule) were controlled by adopting conventional methods of the region. All records were taken during the plant growth.

At maturity, after eliminating the marginal lines on both sides of each plot, all plants in the harvest area $\left(6 \mathrm{~m}^{2}\right)$ were selected and cut at above ground level. The crop was harvested at a grain moisture content of about $20-25 \%$ wet basis. Grain yield was calculated as $\mathrm{kg} \mathrm{ha}^{-1}$ at $14 \%$ moisture content. The rice panicles in the final-harvesting area were counted, and their average was reported as the number of panicles per square meter. The number of grains per panicle was computed from the randomly selected plants in each plot. For the same samples, twenty panicles from each plot were randomly chosen. The main panicle fertility percentage was measured based on the grain number in the main panicle and the number of sterile (non-fertile) flowers. The filled/fertile grains were then randomly selected from the grain samples corresponding to each plot and the mean weight of 10 replications of 100 grains multiplied by 10 reported as 1000-grain weight (g).

The experimental data were subjected to statistical verification with Fishers analysis of variance (ANOVA) using the SAS 9.1 statistical software package. Means were separated based on multiple range test of Duncan (MSRT) at a 0.05 probability level. Bar graphs were depicted using Excel (Microsoft, Redmond, WA, United States).

Correlation coefficients of Pearson were calculated on the traits studied for the correlation analysis. The R package 'Corrgram' was employed to display the correlations between the selected traits by using a 'correlogram' (Asters et al., 2014). A correlogram was a direct visual display of the matrix of Pearson coefficients that were estimated from the experimental data. By this method, correlations between traits were displayed by grouping traits that have similar characteristics, and the values and signs of the correlations were visualised schematically in numbers and 
Tab. 1. Plant parameters of Iranian hybrid rice Oryza sativa L. 'Bahar 1' as affected by foliar spraying of nitrogen fertiliser and timing of application

\begin{tabular}{|c|c|c|c|c|c|c|}
\hline \multirow[b]{2}{*}{$\begin{array}{l}\text { Source } \\
\text { of variation }\end{array}$} & \multirow[b]{2}{*}{$\mathrm{df}$} & \multicolumn{5}{|c|}{ Mean Square } \\
\hline & & $\begin{array}{l}1000 \text { grain } \\
\text { weight }[\mathrm{g}]\end{array}$ & $\begin{array}{c}\text { Panicle } \\
\text { fertility rate } \\
{[\%]}\end{array}$ & $\begin{array}{c}\text { Grain } \\
\text { number per } \\
\text { panicle }\end{array}$ & $\begin{array}{l}\text { Panicle } \\
\text { number per } \\
\text { unit area }\end{array}$ & $\begin{array}{l}\text { Grain yield } \\
\left(\mathrm{kg} \mathrm{ha}^{-1}\right)\end{array}$ \\
\hline $\mathrm{R}$ & 2 & $0.03 \mathrm{~ns}$ & $7.03 \mathrm{~ns}$ & $222.94 \mathrm{~ns}$ & $31.26 \mathrm{~ns}$ & $202632.62 \mathrm{~ns}$ \\
\hline A & 2 & $0.26 \mathrm{~ns}$ & $364.38^{\star *}$ & $1999.83^{\star *}$ & $9151.98^{\star *}$ & $5126514.14^{\star \star}$ \\
\hline linear $\mathrm{A}$ & 1 & $0.15 \mathrm{~ns}$ & $671.36^{\star *}$ & $3957.53^{\star \star}$ & $16642.17^{\star \star}$ & $10076519.95^{\star *}$ \\
\hline quadratic A & 1 & $0.36 \mathrm{~ns}$ & $57.39^{\star}$ & $42.13 \mathrm{~ns}$ & $1661.78^{\star *}$ & $176562.32 \mathrm{~ns}$ \\
\hline B & 2 & $0.04 \mathrm{~ns}$ & $45.6^{\star}$ & $23.36 \mathrm{~ns}$ & $421.16 \mathrm{~ns}$ & $1256327.58^{\star}$ \\
\hline linear B & 1 & $0.07 \mathrm{~ns}$ & $47.46^{*}$ & $11.20 \mathrm{~ns}$ & $650.4 \mathrm{~ns}$ & $2266943.83^{*}$ \\
\hline quadratic B & 1 & $0.001 \mathrm{~ns}$ & $11.74 \mathrm{~ns}$ & $35.52 \mathrm{~ns}$ & $191.91 \mathrm{~ns}$ & $245711.34 \mathrm{~ns}$ \\
\hline $\mathrm{A} \times \mathrm{B}$ & 4 & $0.16 \mathrm{~ns}$ & $7.32 \mathrm{~ns}$ & $24.77 \mathrm{~ns}$ & $24.80 \mathrm{~ns}$ & $84789.78 \mathrm{~ns}$ \\
\hline error & 16 & 0.17 & 11.93 & 136.21 & 128.83 & 320634.79 \\
\hline CV [\%] & - & 1.94 & 5.19 & 6.88 & 4.59 & 9.59 \\
\hline \multicolumn{2}{|l|}{ Treatments } & \multicolumn{5}{|c|}{ Experimental Means } \\
\hline \multirow{3}{*}{$\begin{array}{l}\text { Foliar application at till- } \\
\text { ering }(\mathrm{A}) \\
\mathrm{kg} \mathrm{ha}^{-1}\end{array}$} & $\mathrm{~A}_{1}$ & a 21.26 & a 73.70 & c 154.01 & c 211.30 & c 5101.10 \\
\hline & $\mathrm{A}_{2}$ & a 21.10 & b 64.50 & b 171.49 & b 258.35 & b 6020.90 \\
\hline & $\mathrm{A}_{3}$ & a 21.44 & b 41.67 & a 183.67 & a 272.11 & a 6597.60 \\
\hline \multirow{3}{*}{$\begin{array}{l}\text { Foliar application at } \\
\text { booting (B) } \\
\mathrm{kg} \mathrm{ha}^{-1}\end{array}$} & $\mathrm{~B}_{1}$ & a 21.34 & b 63.99 & a 169.74 & b 293.36 & b 5484.20 \\
\hline & $\mathrm{B}_{2}$ & a 21.26 & a 67.47 & a 168.01 & a 251.02 & ab 6041.00 \\
\hline & $\mathrm{B}_{3}$ & a 21.21 & a 68.19 & a 171.32 & a 251.38 & a 6194.00 \\
\hline
\end{tabular}

Notes: ${ }^{*}-\mathrm{p}<0.05,{ }^{*}-\mathrm{p}<0.01, \mathrm{~ns}-\mathrm{p}>0.05 ; \mathrm{df}-$ degrees of freedom, $\mathrm{R}-$ replication, $\mathrm{A}$ - tillering effect, $\mathrm{B}$ - booting effect; $\mathrm{A} \times \mathrm{B}$ - represent interaction terms between the treatment factors; $\mathrm{CV}$ [\%] - coefficient of variation, means in each column, down-parts of table 1 , followed by the different letters are significantly different $(\mathrm{p}<0.05)$ according to Duncan test; $\mathrm{A} 1, \mathrm{~B} 1$ : Control or no $\mathrm{N}$ fertilisation, A2, B2: $10 \mathrm{~kg} \mathrm{~N} \mathrm{ha}^{-1}$ $\approx 22 \mathrm{~kg}$ urea ha- ${ }^{-1}, \mathrm{~A} 3, \mathrm{~B} 3: 20 \mathrm{~kg} \mathrm{~N} \mathrm{ha}^{-1} \approx 44 \mathrm{~kg}$ urea ha $^{-1}$

colour-coded pie graphs. The pie graphs were filled in proportion to the Pearson coefficient values, counter clockwise for negative correlations (in red) and clockwise or positive correlations (in blue).

Results and Discussion

Panicle number per unit area

In this study, the number of panicles per unit area, being the most important components of grain yield, was strongly influenced by the time of fertilising, in a way that the foliar spraying of urea fertiliser at the tillering stage showed a highly significant effect $(\mathrm{p}<0.01)$, while it left no effect at the booting stage (Tab. 1). The result would likely reflect the superior impact of urea fertiliser at the time of tillering in improving the number of reproductive units per unit area. Generally, the number of 
productive panicles per plant is determined during the reproductive phase (Singh et al., 2014). This indicates the hypothesis that most of the nitrogen foliar-sprayed at booting was utilised for improving the fertility rate of panicles rather than their quantity (Dorosti, 2009).

The interaction effect of foliar feeding of urea at different stages of tillering and booting was found to be non-significant on the number of panicles. A comparison of means associated with the tillering stage showed that, by gradual increasing of urea fertiliser application, the number of panicles per unit area increased as well. The highest (272.1) and the lowest (211.3) number of panicles belonged to those of plots enriched with 20 and $0 \mathrm{~kg}$ of $\mathrm{N}$ per hectare (Fig. 1, Tab. 1). It is suggesting that the plant behaviour is completely proportional to the amount of urea being applied at tillering, and that the relationship between the number of panicles per unit area and the rate of urea fertiliser is slightly of a quadratic equation. In other words, nitrogen application up to level of $10 \mathrm{~kg} \mathrm{ha}^{-1}$ drastically enhanced the number of panicles by $22 \%$, and any further application contributed to only a $5 \%$ increase in panicle number, indicating that an extra $\mathrm{N}$ input was utilised for other processes (Liu et al., 2016). In support to our findings, Kazemeini and Ghadiri (2005), Peng et al. (2010) and more recently Cao et al., (2013) documented a noticeable decrease in photosynthetic $\mathrm{N}$ use efficiency under an elevated use of $\mathrm{N}$ fertiliser.

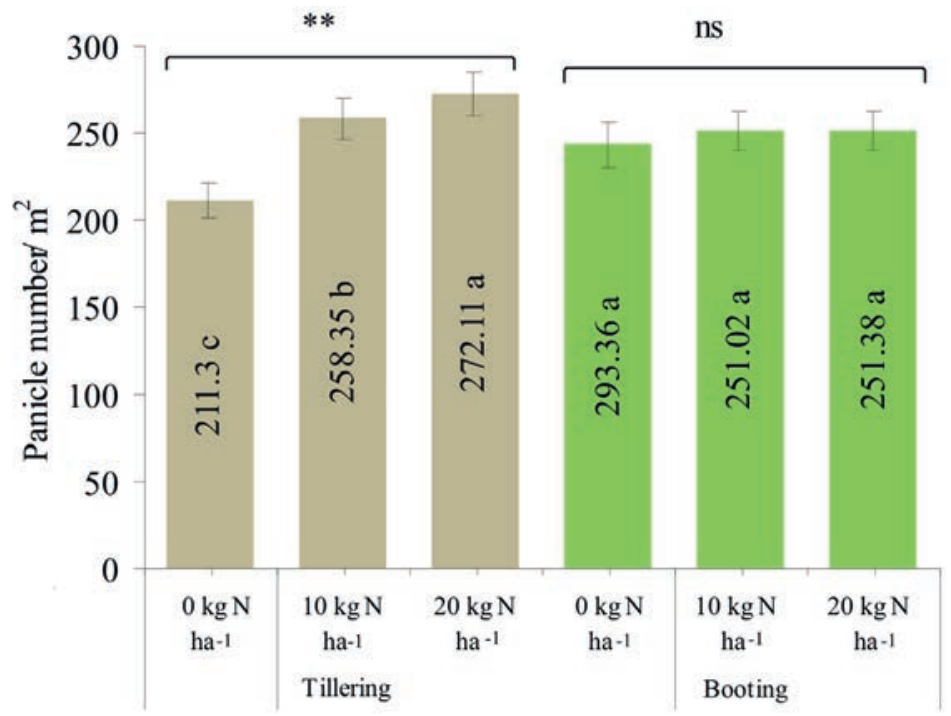

Fig. 1. Influence of foliar applied $\mathrm{N}$ fertiliser $\left(0 \mathrm{~kg} \mathrm{~N} \mathrm{ha}^{-1,} 10 \mathrm{~kg} \mathrm{~N} \mathrm{ha}^{-1} \approx 22 \mathrm{~kg}\right.$ urea ha ${ }^{-1}, 20 \mathrm{~kg} \mathrm{~N} \mathrm{ha}^{-1} \approx 44$ $\mathrm{kg}$ urea ha $\mathrm{h}^{-1}$ ) on panicle number per square meter; urea was applied in solution with $5 \%$ dry matter basis; Significant differences between the treatments in tillering and booting stages are indicated with asterisks $\left({ }^{*}-\mathrm{p}<0.05,{ }^{* *}-\mathrm{p}<0.01, \mathrm{~ns}-\mathrm{p}>0.05\right.$, Duncan multiple range test); The error bars denote the standard deviation $( \pm S D)$ of the mean value; $n=6$ 


\section{Grain number per panicle}

Foliar spraying of urea in the tillering stage significantly $(\mathrm{p}<0.01)$ and linearly affected the number of grains generated in each panicle, while it had no effect on this trait during the booting stage. In other words, the number of grains in panicles of those plants receiving foliar spray of $\mathrm{N}$, by the booting stage, did not differ significantly from that of untreated check plants, suggesting that the $\mathrm{N}$ fertiliser was exploited for other processes, such as improving panicles quality. The number of grains per panicle is mainly associated with the factors influencing the growth parameters right before the initiation of pollination process. Accordingly, any defect in these requisite factors could likely reduce the grain number per panicle (Dorosti, 2009). Thus, the availability of nitrogen through foliar spraying of urea prior to the formation of panicle could be the main reason for its effectiveness in increasing the grain number per panicle. A comparison of mean values shows that the highest number of grains per panicle (183.6) was achieved by the application of $20 \mathrm{~kg} \mathrm{~N} \mathrm{ha}^{-1}$ at the tillering stage, followed by $10 \mathrm{~kg}$ $\mathrm{N} \mathrm{ha}^{-1}$, and the lowest value (154) was recorded in the untreated (non-sprayed) check plants (Fig. 2, Tab. 1). Liu et al. (2016), in their study on yield of lowland rice receiving $\mathrm{N}$ fertilisation treatment, concluded that the increase in the number of grains per panicle was in extremely close association with nitrogen application rate under constant submerged condition.

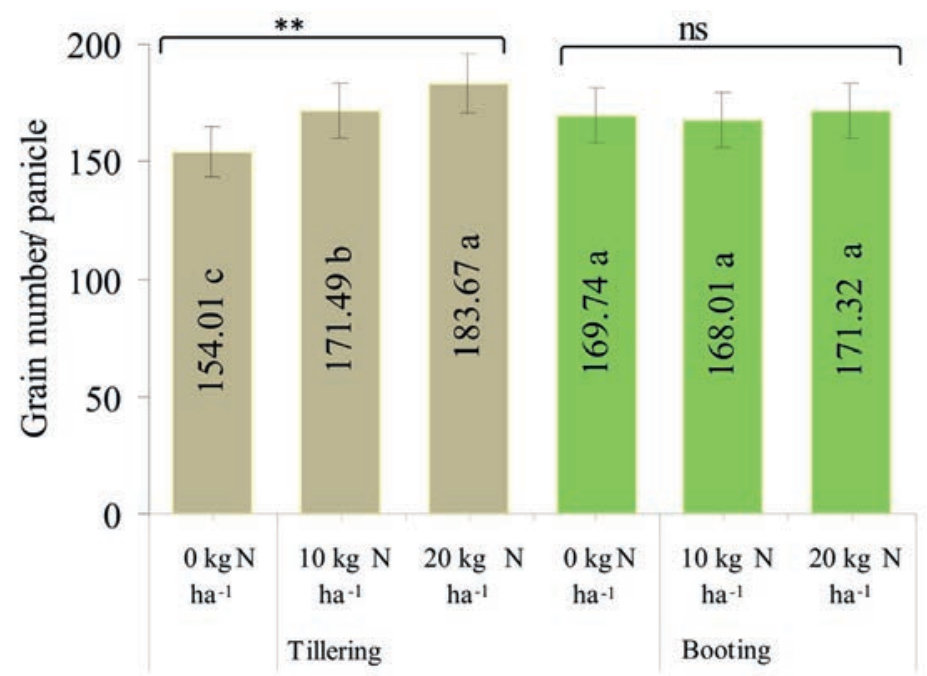

Fig. 2. Influence of foliar applied $\mathrm{N}$ fertiliser $\left(0 \mathrm{~kg} \mathrm{~N} \mathrm{ha}^{-1}, 10 \mathrm{~kg} \mathrm{~N}^{-1} \approx 22 \mathrm{~kg}^{-1} \mathrm{urea} \mathrm{ha}^{-1}, 20 \mathrm{~kg} \mathrm{~N} \mathrm{ha}^{-1}\right.$ $\approx 44 \mathrm{~kg}$ urea $\mathrm{ha}^{-1}$ ) on grain number per panicle; urea was applied in solution with $5 \%$ dry matter basis; Significant differences between the treatments in tillering and booting stages are indicated with asterisks $\left({ }^{*}-\mathrm{p}<0.05,{ }^{* *}-\mathrm{p}<0.01, \mathrm{~ns}-\mathrm{p}>0.05\right.$, Duncan multiple range test); The error bars denote the standard deviation $( \pm \mathrm{SD})$ of the mean value ; $\mathrm{n}=6$ 
The data shows that the panicle fertility percentage (seed setting) was significantly different according to the timing of urea spraying (Fig. 3). A comparison of means regarding the levels of nitrogen fertiliser at the active tillering stage shows that the number of filled grains in the panicles decreased by increasing the amount of urea fertiliser. The maximum value of fertile panicles were recorded in untreated check plants (73.7), followed by $10 \mathrm{~kg} \mathrm{~N} \mathrm{Na}^{-1}$ (64.5), which was on par with $20 \mathrm{~kg} \mathrm{~N} \mathrm{ha}^{-1}$ (61.47) (Tab. 1). A notable reduction in the fertility percent of panicles was observed in return for enhanced $\mathrm{N}$ application in the tillering stage, which might be due to an increased number of infertile (or non-productive) tillers and panicles per unit area (Akhgari, 2010). Srividya et al. (2010) pointed out that an excess application of $\mathrm{N}$ input could increase the number of chaffy (unfilled) grains or sterile spikelets in a relatively high responsive manner to $\mathrm{N}$ fertilisation in comparison with optimum $\mathrm{N}$ dose. Urea spraying at the booting stage also had a significant effect on the percentage of fertile panicles $(p<0.05)$. The number of filled grains in the panicles was increased in line with the increased level of urea fertiliser. Urea application that augment plant nitrogen before heading (at booting stage) can be highly effective in giving rise to the number of filled grains and/ or spikelets (Kamiji et al., 2011). Fertiliser levels of 10 and $20 \mathrm{~kg}$ $\mathrm{N} \mathrm{ha}^{-1}$, being on par with each other, was better than no spraying and revealed the appropriate timing for $\mathrm{N}$ application at this stage. Interaction between foliar feeding of $\mathrm{N}$ and developmental stages of tillering and booting was found to be non-significant. Mingotte et al. (2013) believed that, if the $\mathrm{N}$ fertiliser supplementation is applied in the period that the spikelets initiated differentiation in the panicle, the plant itself does not encounter any problem regarding $\mathrm{N}$ deficiency, especially when initiating flower primordia, and hence it will produce more filled grains. Singh et al. (2014) demonstrated that the number of unfilled (sterile spikelets) rice panicles could be multiplied with the excess application of nitrogen as compared with the optimum $\mathrm{N}$ level. Indeed, a further increase in $\mathrm{N}$ levels decreases the physiological nitrogen-use efficiency by reducing the nitrogen content in leaves to be remobilized during grain feeling (Cao et al., 2013; Kant et al., 2011).

\section{Thousand grain weight}

Thousand grain weight (TGW) is a complex quantitative genetic trait for rice and is one of the three key factors that influence the grain yield (Wei et al., 2014). The grain weight is a highly stable varietal character (Fageria et al., 2011) that is determined during the ripening phase. There was no influence of urea fertilisation on TGW ( $p$ > 0.05 ) at both the growth stages (tillering and booting). Under urea fertiliser treatment, TGW varied from 21.1 to $21.44 \mathrm{~g}$ (tillering stage; average value of $21.3 \mathrm{~g}$ ) and from 20.26 to $21.34 \mathrm{~g}$ (booting stage; average value of $21 \mathrm{~g}$ ) (Tab. 1). Fageria et al. (2011) re- 


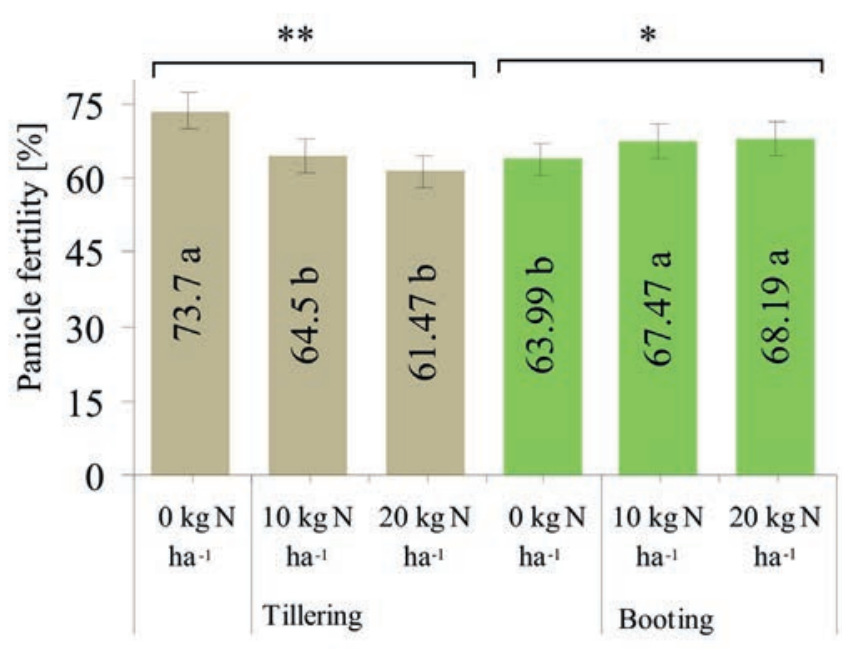

Fig. 3. Influence of foliar applied $\mathrm{N}$ fertiliser $\left(0 \mathrm{~kg} \mathrm{~N} \mathrm{ha}^{-1,} 10 \mathrm{~kg} \mathrm{~N}\right.$ ha $^{-1} \approx 22 \mathrm{~kg}$ urea ha ${ }^{-1}, 20 \mathrm{~kg} \mathrm{~N} \mathrm{ha}^{-1} \approx$ $44 \mathrm{~kg}$ urea ha $\mathrm{h}^{-1}$ ) on panicle fertility percentage; urea was applied in solution with $5 \%$ dry matter basis; Significant differences between the treatments in tillering and booting stages are indicated with asterisks $\left({ }^{*}-\mathrm{p}<0.05,{ }^{*}-\mathrm{p}<0.01, \mathrm{~ns}-\mathrm{p}>0.05\right.$, Duncan multiple range test); The error bars denote the standard deviation $( \pm \mathrm{SD})$ of the mean value $\mathrm{n}=6$

ported TGW of lowland rice genotype 'BRSGO Guar' varied from 21.1 to $24.6 \mathrm{~g}$, with an average value of $23.0 \mathrm{~g}$. Similar results were also documented in those of previous studies that reported the lack of influence of soil (Azarpour et al., 2011) and foliar (Asadi et al., 2011, 2014) application of nitrogen on TGW between the genotypes tested. Sarwa et al. (2011) also stated that thousand-grain weight depends on the genetic constitution and is less affected by growing conditions. The natural conditions and environment are believed to have more interference in determining grain quantity (seed size) rather than inherent factors (Wei et al., 2014).

\section{Grain yield}

In the present study, the grain yield was significantly and linearly affected by various foliar $\mathrm{N}$ fertiliser levels at both the tillering $(\mathrm{p}<0.01)$ and booting $(\mathrm{p}<0.05)$ stages, while no interactive effect was noticed among the different combination treatments (Fig. 4, Tab. 1). The differences in the grain yield were largely because of variations in the yield components, including the number of grains per panicle, the number of panicles per unit area, panicle fertility percent, and thousand-grain weight (Hasanuzzaman et al., 2009). The comparison of means at the tillering stage revealed that the grain yield was increased by applying the amount of $\mathrm{N}$ fertiliser from 0 to $20 \mathrm{~kg} \mathrm{ha}^{-1}$. The treatment $20 \mathrm{~kg} \mathrm{~N} \mathrm{ha}^{-1}$ resulted in the highest rice grain yield $\left(6597 \mathrm{~kg} \mathrm{ha}^{-1}\right)$, which was followed by $10 \mathrm{~kg} \mathrm{~N} \mathrm{ha}^{-1}\left(6020 \mathrm{~kg} \mathrm{ha}^{-1}\right)$. This dose was found to be superior to $10 \mathrm{~kg} \mathrm{~N} \mathrm{ha}^{-1}$ treatment and control. The lowest grain yield was observed in untreat- 
ed/ unsprayed check plants. The linear increase in grain yield with increasing foliar $\mathrm{N}$ fertiliser rates may be associated with more grain, panicle, and/or tiller number produced per plant (Tab. 1). Furthermore, the positive and significant relationship between the grain yield and the number of panicles per unit land area at harvest time (Xu et al., 2015) might be an indicative of this result. There was a significant and linear increase in grain yield with increasing $\mathrm{N}$ rates with urea in the booting stage. In other words, grain yield was significantly improved in a linear fashion when $\mathrm{N}$ rates increased from 0 to $20 \mathrm{~kg} \mathrm{ha}^{-1}$ by urea fertilisation. Maximum grain yield was achieved at $20 \mathrm{~kg} \mathrm{~N} \mathrm{ha}^{-1}\left(6194 \mathrm{~kg} \mathrm{ha}^{-1}\right)$, which was on par with $10 \mathrm{~kg} \mathrm{~N} \mathrm{ha}^{-1}$ treatment $\left(6041 \mathrm{~kg} \mathrm{ha}^{-1}\right)$. The increase in grain yield may be attributed to the high fertility percentage of panicles in return for increasing $\mathrm{N}$ rates during the booting stage. Mingotte et al. (2013), working with nitrogen topdressing, obtained the highest rice yield when foliar $\mathrm{N}$ application was made before the crop was headed (panicle differentiation). Our results are consistent with recently released investigations in terms of the existence of a noticeable increase in grain yield after foliar spraying of $\mathrm{N}$ fertiliser in maximum tillering (Asadi et al., 2011, 2014) and booting stages (Asadi et al., 2014, 2015).

\section{Correlations between the examined traits}

To determine if there were associations between all the tested traits, correlation analysis was performed on mean values derived out of ANOVA analysis, and the

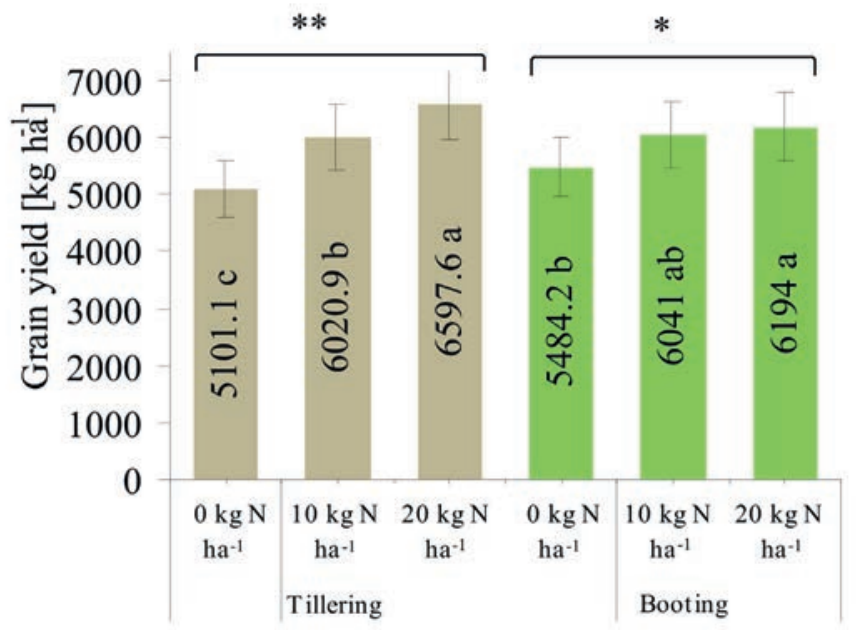

Fig. 4. Influence of foliar applied $\mathrm{N}$ fertiliser $\left(0 \mathrm{~kg} \mathrm{~N} \mathrm{ha}^{-1,} 10 \mathrm{~kg} \mathrm{~N} \mathrm{ha}^{-1} \approx 22 \mathrm{~kg}\right.$ urea ha-1, $20 \mathrm{~kg} \mathrm{~N}$ $\mathrm{ha}^{-1} \approx 44 \mathrm{~kg}$ urea ha ${ }^{-1}$ ) on grain yield as $\mathrm{kg} \mathrm{ha}^{-1}$; urea was applied in solution with $5 \%$ dry matter basis; Significant differences between the treatments in tillering and booting stages are indicated with asterisks $\left({ }^{*}-\mathrm{p}<0.05,{ }^{* *}-\mathrm{p}<0.01, \mathrm{~ns}-\mathrm{p}>0.05\right.$, Duncan multiple range test); The error bars denote $( \pm S D) ; \mathrm{n}=6$ 
correlation matrices were visualised schematically by using R package 'Corrgram' (Fig. 5). Correlations displayed in a correlogram were organised in the order that traits having similar characteristics were grouped together. The colour-coded pie graphs were reflected in the upper triangle, and the values and signs of the Pearson coefficients were represented schematically with the correlation coefficients and the $95 \%$ confidence intervals displayed in the lower triangle. Yield related traits, i.e. grain yield (GY), and grain number per panicle (GN.P) were found positively correlated to each other with a coefficient being at least $0.9(\mathrm{p}<0.05)$. GN.P were also noticed to be correlated to panicle number per square meter (PN.SM; $r: 0.72 ; \mathrm{p}>0.05$ ) and thousand grain weight (TGW; $r: 0.39 ; \mathrm{p}>0.05$ ), and negatively correlated with panicle fertility rate (PFR; $r:-0.88 ; \mathrm{p}<0.05$ ). No significant association was recorded for TGW. As per correlation coefficients results associated with PFR, our study showed a close/ direct association between the number of chaffy grains and GN.P, which suggested that the mitigation of grain number per panicle is likely involved in enhancement of fertility rate.

\section{Conclusions}

Nitrogen is believed to be the most constraining factor on crop production in many of the world's agricultural regions, and its efficacious adoption is indispensable for the frugal sustainability of cropping systems. Moreover, the dynamic nature of this element and its inherent tendency for loss from soil-plant systems creates a challenging and peerless space for its optimal management. Foliar fertilisation technique may also be a good alternative to the convectional soil application to avoid the risk of fixation or leaching of nutrients.

These results clearly showed that foliar-applied urea at active tillering could have a better performance once applied at higher concentrations $\left(\approx 44 \mathrm{~kg}_{\mathrm{urea} \mathrm{ha}}{ }^{-1}\right)$. As an instance, the grain number per panicle and panicle number per unit area increased to about 19.26 and $28.78 \%$, respectively, compared with those of untreated check plots. Plants fertilised with a lower dose of urea $\left(10 \mathrm{~kg} \mathrm{~N} \mathrm{ha}^{-1} \approx 22 \mathrm{~kg}\right.$ urea ha $\left.{ }^{-1}\right)$ in the booting stage gave the more appropriate performance for both the panicle fertility rate and grain yield. In other words, high $\mathrm{N}$ fertiliser application exceeding $10 \mathrm{~kg} \mathrm{ha}^{-1}$ in the boot stage has likely resulted in a considerable decline in $\mathrm{N}$ use efficiency and could lead to an increased $\mathrm{N}$ loss risk. Thousand-grain weight was not appreciably affected by urea fertilisation timing, since it is mostly governed by genetic constitution.

Although, the different concentrations of urea fertiliser at two stages of growth were used, further investigations relying on timing and other concentrations are needed to be undertaken in different agro-ecological regions. 


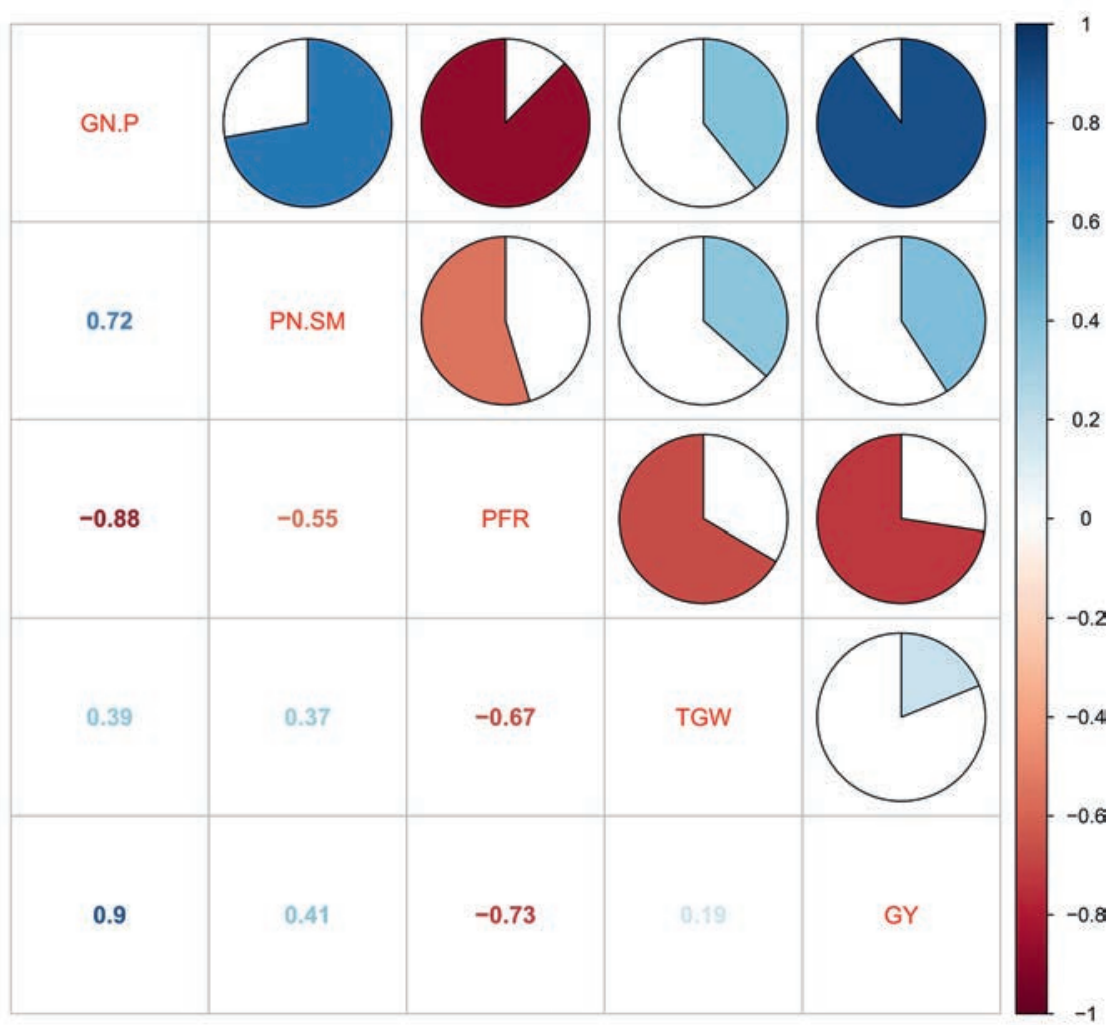

Fig. 5. Correlogram display of correlation matrices for experimental data (Grain yield: GY, Thousand grain weight: TGW, Panicle fertility rate: PFR, Panicle number per square meter: PN.SM; Gran number per panicle: GN.P); The pie graphs are filled in proportion to the Pearson's coefficient values, clockwise for positive correlations (in blue) and anti-clockwise for negative correlations (in red); The numbers are Pearson coefficients with 95\% confidence intervals

\section{References}

Ahmadi, K., Gholizadeh, H., Ebadzadeh, H.R., Hosseinpour, R., Hatami, F., Fazli, B., Kazemian, A. Rafiei. M. (2014). Agricultural statistics of Iran: Crop plants. Tehran, Iran: Ministry of Agriculture Jihad Press. [In Persian]

Akhgari, H. (2010). Rice (Agronomy, Fertilization, and Nutrition). Rasht, Iran: Islamic Azad University Press. [In Persian]

Asadi, S.S., Zavareh, M., Vahed, H.S., Shahinrokhsar, P. (2011). Effect of supplement foliar application of nitrogen and potassium on yield, grain quality and nitrogen utilization efficiency of hybrid rice var. Bahar-1. Electronic Journal of Crop Production, 4(3), 175-190. [In Persian]

Asadi, S.S., Zavareh, M., Vahed, H.S., Shahinrokhsar, P. (2014). Effect of foliar application of nitrogen and potassium on yield and yield components of hybrid rice (Oryza sativa cv. Daylam). Journal of Crops Improvement (Journal of Agriculture), 16(3), 693-706.

Asadi, S.S., Zavareh, M., Vahed, H.S., Shahinrokhsar, P. (2015). Influence of supplemental foliar application of nitrogen and potassium on the grain yield, concentration and efficiency of nitrogen in rice (Oryza sativa L.). Agronomy Journal (Pajouhesh \& Sazandegi), 108, 127-136. [In Persian] 
Asters, M.C., Williams, W.P., Perkins, A.D., Mylroie, J.E., Windham, G.L., Shan, X. (2014). Relating significance and relations of differentially expressed genes in response to Aspergillus flavus infection in maize. Scientific Reports, 4, 4815. DOI: 10.1038/srep04815.

Azarpour, E., Amiri, E., Kashani, A., Khodabande, N., Moradi, M. (2011). Effect of nitrogen fertilizer different levels on yield and yield components of current rice cultivars in two locations: Rasht and Rudsar. Electronic Journal of Crop Production, 4(3), 209-218. [In Persian]

Bhuyan, M.H.M., Ferdousi, M.R., Iqbal., M.T. (2012). Foliar spray of nitrogen fertilizer on raised bed increases yield of transplanted aman rice over conventional method. International Scholarly Research Notices Agronomy, ID 184953, 1-8. DOI: 10.5402/2012/184953.

Britzke, D., da Silva, L.S., Moterle, D.F., Rheinheimer, D.S., Bortoluzzi, E.C. (2012). A study of potassium dynamics and mineralogy in soils from subtropical Brazilian lowlands. Journal of Soils and Sediments, 12(2), 185-197. DOI 10.1007/s11368-011-0431-7

Brown, B.D., Petrie, S. (2006). Irrigated hard winter wheat response to fall, spring, and late season applied nitrogen. Field Crops Research, 96, 260-268. DOI: 10.1016/j.fcr.2005.07.011

Cao, Y.S., Tian, Y.H., Yin, B., Zhu, Z.L. (2013). Assessment of ammonia volatilization from paddy fields under crop management practices aimed to increase grain yield and $\mathrm{N}$ efficiency. Field Crops Research, 147, 23-31. DOI: 10.1016/j.fcr.2013.03.015

Dorosti, H. (2009). The recently released high quality hybrid rice with proposed name of Bahar 1. Final report No. 86/1633, Rice Research Institute of Iran, Agricultural Research, Education and Extension Organization, Ministry of Agriculture Jihad, Rasht, Iran. [In Persian]

Fageria, N.K. (2013). Nitrogen. In: N.K. Fageria (ed.), Mineral Nutrition of Rice. Croatia: CRC Press, 105-190. DOI: 10.1201/b15392

Fageria, N.K., dos Santos, A.B., Coelho, A.M. (2011). Growth, yield and yield components of lowland rice as influenced by ammonium sulfate and urea fertilization. Journal of Plant Nutrition, 34, 371-386. DOI: 10.1080/01904167.2011.536879

Hasanuzzaman, M., Nahar, K., Alam, M.M., Hossain, M.Z., Islam, M.R. (2009). Response of transplanted rice to different application methods of urea fertilizer. International Journal of Sustainable Agriculture, 1(1), 1-5.

IRRI (International Rice Research Institute). 2008. Background paper: the rice crisis: What needs to be done? Los Baños (Philippines): IRRI. http://www.irri.org.

Kamiji, Y., Yoshida, H., Palta, J.A., Sakuratani, T., Shiraiwa. T.N. (2011). Applications that increase plant $\mathrm{N}$ during panicle development are highly effective in increasing spikelet number in rice. Field Crops Research, 122, 242-247. DOI: 10.1016/j.fcr.2011.03.016

Kant, S., Bi, Y.M., Rothstein, S.J. (2011). Understanding plant response to nitrogen limitation for the improvement of crop nitrogen use efficiency. Journal of Experimental Botany, 62, 1499-1509. DOI: $10.1093 /$ jxb/erq297

Liu, C.W., Sung, Y., Chen, B.C., Lai, H.Y. (2014). Effects of nitrogen fertilizers on the growth and nitrate content of lettuce (Lactuca sativa L.). International Journal of Environmental Research and Public Health, 11(4), 4427-4440. DOI: 10.3390/ijerph110404427

Liu, X., Wang, H., Zhou, J., Hu, F., Zhu, D., Chen, Z., Liu, Y. (2016). Effect of N fertilization pattern on rice yield, $\mathrm{N}$ use efficiency and fertilizer-N fate in the Yangtze River Basin, China. PLOS ONE, 11(11), e0166002. DOI: 10.1371/journal.pone.0166002

Mingotte, F.L.C., Hanashiro, R.K., Filho, D.F. (2013). Response of rice cultivars to nitrogen in upland conditions. Revista Ceres, 60(1), 86-95. DOI: 10.1590/S0034-737X2013000100013

Mondal, A.B., Al-Mamun, A. (2011). Effect of foliar application of urea on the growth and yield of tomato. Frontiers of Agriculture in China, 5(3), 372-374. DOI: 10.1007/s11703-011-1089-z 
Norton, J.B. (2011). Nitrogen source, timing, and rate alternatives for furrow-irrigated sugar beet. Crop Management, 10(1), 1-12. DOI: 10.1094/CM-2011-0829-01-RS

Ravikumar, P., Somashekar, R.K. (2013). Evaluation of nutrient index using organic carbon, available P and available $\mathrm{K}$ concentrations as a measure of soil fertility in Varahi River basin, India. Proceedings of the International Academy of Ecology and Environmental Sciences, 3(4), 330-343.

Sarwa, N., Maqsood, M., Wajid, S.A., Anwar-ul-Hag, M. (2011). Impact of nursery seeding density, nitrogen, and seedling age on yield and yield attributes of fine rice. Chilean Journal of Agricultural Research, 7(3), 343-349.

Shen, J., Li, C., Mi, G., Li, L., Yuan, L., Jiang, R., Zhang, F. (2013). Maximizing root/rhizosphere efficiency to improve crop productivity and nutrient use efficiency in intensive agriculture of China. Journal of Experimental Botany, 64(5), 1181-1192. DOI: 10.1093/jxb/ers342

Shirani Rad, A.H., Zandi, P. (2014). Agronomic evaluation of rapeseed varieties (Brassica napus L.) in response to late-season water deficit stress. Agriculturae Conspectus Scientificus, 79(3), 157-165.

Singh, H., Verma, A., Ansari, M.W., Shukla, A. (2014). Physiological response of rice (Oryza sativa L.) genotypes to elevated nitrogen applied under field conditions. Plant Signaling \& Behavior, 9, e29015. DOI: 10.4161/psb.29015.

Srividya, A., Vemireddy, L.R., Hariprasad, A.S., Jayaprada, M., Sridhar, S. (2010). Identification and mapping of landrace derived QTL associated with yield and its components in rice under different nitrogen levels and environments. International Journal of Plant Breeding and Genetics, 4(4), 210-227. DOI: 10.3923/ijpbg.2010.210.227

Tavakoli, M.T., Chenari, A.I., Rezaie, M., Tavakoli, A., Shahsavari, M., Mousavi, S.R. (2014). The importance of micronutrients in agricultural production. Advances in Environmental Biology, 8(10), 31-35.

Tousikehal, P., Esfahani, M., Rabiei, M., Rabiei, B. (2011). Effect of concentration and timing of application of supplementary nitrogen fertilizer on dry matter remobilization, grain yield and yield components of rapeseed (Brassica napus L.) cv. Hayola 401). Iranian Journal of Crop Science, 13(2), 352-367. [In Persian]

Wei, L., Li, J.M., Hou, X.J., Wang, X., Li, H.Q., Zhang, B., Chen, W.J., Liu, D., Liu, B.L., Zhang, H.G. (2014). QTL positioning of thousand wheat grain weight in Qaidam Basin. Open Journal of Genetics, 4, 239-244. DOI: 10.4236/ojgen.2014.43024

Xie, F., Hardy, B. (2009). Accelerating hybrid rice development. Los Baños, Philippines: International Rice Research Institute, 379-404.

$\mathrm{Xu}, \mathrm{Q}$., Chen, W., Xu, Z. (2015). Relationship between grain yield and quality in rice germplasms grown across different growing areas. Breeding Science, 65(3), 226-232. DOI: 10.1270/jsbbs.65.226

Yousefi, M., Zandi, P. (2012). Effect of foliar application of zinc and manganese on yield of pumpkin (Cucurbita pepo L.) under two irrigation patterns. Electronic Journal of Polish Agricultural Universities, 15(4), \#02.

Zandi, P., Basu, S.K. (2016). Role of plant growth-promoting rhizobacteria (PGPR) as biofertilizers in stabilizing agricultural ecosystems, Chapter 3. In: D. Nandwani (ed.), Organic Farming for Sustainable Agriculture. Germany: Springer International Publishing, 71-87. DOI: 10.1007/978-3-319-26803-3_3

Abstract

Because of waterlogged conditions in rice cultivation, much of the surface-broadcasted urea dissolves in paddy water and is unreachable to the rice crop for this reason. A field experiment was conducted to estimate the influence of urea fertilisation on yield and yield components of hybrid rice 'Bahar 1'. Three doses $\left(\mathrm{N}_{0}, \mathrm{~N}_{10}, \mathrm{~N}_{20} \mathrm{~kg} \mathrm{~N} \mathrm{ha}^{-1}\right)$ of nitrogen from urea sources were foliar-sprayed once at active tillering and booting stages. Grain yield, the number of panicles per unit area, and the number of grains per panicle in the tillering 
stage of rice were significantly $(\mathrm{p}<0.01)$ increased in a linear fashion when $\mathrm{N}$ rates increased from 0 to $20 \mathrm{~kg}$ $\mathrm{ha}^{-1}$. The rate of panicle fertility was negatively/positively influenced with increasing $\mathrm{N}$ rates in the tillering and booting stages, respectively, indicating the creation of more number of non/partial productive tillers per hill in the vegetative stage than in the reproductive stage. In line with panicle fertility (\%), the grain yield was also significantly affected by $\mathrm{N}$ treatments with urea fertilisation in the booting stage. Maximum grain yield was obtained with the application of $20 \mathrm{~kg} \mathrm{~N} \mathrm{ha}^{-1}$ at both the tillering and booting stages. Foliar spraying of urea at tillering $\left(20 \mathrm{~kg} \mathrm{~N} \mathrm{ha}^{-1}\right)$ and booting $\left(10 \mathrm{~kg} \mathrm{~N} \mathrm{ha}^{-1}\right)$ stages had a pronounced effect on achieving higher yields as compared to other combinations. The study suggests that foliar application of urea for hybrid rice cultivation might have a potential role in improving nitrogen use efficiency.

Key words: Oryza sativa L. 'Bahar 1', foliar spraying, urea fertilisation, grain yield

Received: [2017.07.11]

Accepted: [2017.10.31]

\section{Wpływ „dożywiania” dolistnego mocznikiem na plon i jego składniki irańskiego mieszańca ryżu Oryza sativa L. 'Bahar 1 '}

Streszczenie

Ze względu na podmokłe warunki upraw ryżu, większość powierzchniowej transmisji mocznika rozpuszcza się w wodzie gruntowej i z tego powodu nie jest osiągalna dla uprawy ryżu. Przeprowadzono doświadczenie polowe w celu oszacowania wpływu nawożenia mocznikiem na wydajność i składniki plonu mieszańca ryżu Oryza sativa L. 'Bahar 1'. Trzy dawki azotu $\left(\mathrm{N}_{0}, \mathrm{~N}_{10}, \mathrm{~N}_{20} \mathrm{~kg} \mathrm{~N}^{-1}\right)$, pochodzące z zasobów mocznika, były rozpryskiwane na liście ryżu jednorazowo, przed stadiami krzewienia i tworzenia liścia flagowego. Plon ziarna, liczba wiech na jednostkę powierzchni i liczba ziaren przypadających na wiechę w fazie krzewienia ryżu wzrastały istotnie $(\mathrm{p}<0,01) \mathrm{w}$ sposób liniowy, gdy dawki azotu $(\mathrm{N})$ wzrastały od 0 do $20 \mathrm{~kg} \mathrm{ha}^{-1}$. Poziom płodności wiechy był odpowiednio uzależniony od wzrostu dawek azotu $(\mathrm{N}) \mathrm{w}$ stadiach krzewienia i tworzenia liścia flagowego; wskazując na utworzenie większej liczby częściowo nieproduktywnych na wierzchołku źdźbeł w stadium wegetatywnym niż w stadium generatywnym. Z kolei, z płodnością wiech (\%), plon ziarna był także istotnie uzależniony od azotu $(\mathrm{N})$ poprzez traktowanie mocznikiem w stadium tworzenia liścia flagowego. Maksymalna wydajność plonu ziarna uzyskano przy aplikacji $20 \mathrm{~kg} \mathrm{~N}^{-1} \mathrm{w}^{-1}$ obydwu stadiach: krzewienia i tworzenia liścia flagowego. Opryskiwanie liści mocznikiem w fazach krzewienia (20 $\left.\mathrm{kg} \mathrm{N} \mathrm{ha}^{-1}\right)$ i tworzenia liścia flagowego $\left(10 \mathrm{~kg} \mathrm{~N} \mathrm{ha}^{-1}\right)$ miało wyraźny wpływ na uzyskiwanie wyższych plonów, w porównaniu z innymi kombinacjami. Badania wskazują, że dolistne zastosowanie mocznika w uprawie mieszańców ryżu może odgrywać potencjalną rolę w poprawie efektywności wykorzystania azotu.

Słowa kluczowe: Oryza sativa L. 'Bahar 1', spryskiwanie dolistne, nawożenie mocznikiem, plon ziarna

\section{Information on the authors}

\section{Hamid Dorosti}

He obtained his PhD from Gorgan University of Agricultural Sciences and Natural Resources in 2015. Before then, having Master degree in Plant Breeding, he joined RRRI (Rasht rice research institute, Guilan Prov., Iran). He had been involved in several projects performed at RRRI, Rasht, Iran as scientist fellow for over 30 years.

\section{Katarzyna Możdżeń}

Her scientific interests concentrate on the effects of different environmental factors (light, ozone, heavy metals, allelopathic extracts) on the morphology and physiology of cultivated, protected, and invasive species of plants.

\section{Peiman Zandi}

He was deeply trained in agronomy (crop science) and specialising in stress physiology, biotic/abiotic stresses, and agroecology. He is also interested in working in different areas of plant developmental biolo- 
gy, agroecology, plant nutrition, botany, plant breeding, and genetics. His previous research project, which was funded by Payame Noor University (Ganaveh, Iran), was 'Foliar application of ascorbate on the physiological and biochemical attributes of Iranian fenugreek (Trigonella foenum-graecum L.) landraces under drought stress'. Currently, he joined a research group at Chinese Academy of Agricultural Sciences (Beijing, China) attempting to discern the possible function of iron plaque on chromium acquisition, accumulation and translocation in selected rice (Oryza sativa L.) cultivars grown in different planting media. Their main aim is to verify IP role in wetland plants subjected to Si fertilisation as an effective strategy to decrease $\mathrm{Cr}$ accumulation in O. sativa grown in Cr-contaminated environments.

\section{Morteza Siavoshi}

He is an assistant professor and faculty member of agricultural science department in Payame Noor University, Iran. He was awarded his $\mathrm{PhD}$ degree in Agronomy in Pune University, Pune, India. Now he is a college principal in Ganaveh Payame Noor College, Iran. 